\title{
前立腺肥大症患者に対する経尿道的前立腺核出術（HoLEP）における モーセレーション効率と核出重量に関する検討
}

\author{
${ }^{1)}$ 㴊野辺総合病院泌尿器科, ${ }^{2)}$ 北里大学医学部泌尿器科, ${ }^{3)}$ 石川泌尿器科 \\ 石川 隆太 ${ }^{13)}$ 設楽 敏也 ${ }^{1)} \quad$ 若田部陽司 ${ }^{122}$ 久保 星一 ${ }^{1)}$

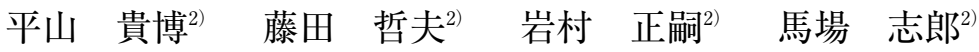

\section{要旨:}

（目的）前立腺肥大症患者に対する経尿道的前立腺核出術（HoLEP）におけるモーセレーション効率と核出 重量の関係について後ろ向きに検討した.

（対象と方法） 2010 年 1 月から 12 月までに単一術者により前立腺肥大症患者に対し HoLEP を施行された 140 例を対象とした。 モーセレーションは hand-piece 反転法で行った.

(結果) 平均年齢は 70.6 歳で, 平均核出重量 $46.8 \mathrm{~g}$, 平均モーセレーション時間 9.9 分, 平均モーセレーショ ン効率 $6.7(\mathrm{~g} / \mathrm{min})$ であった．モーセレーションによる合併症は膀胱損傷を含め 1 例も認めなかった．モーセ

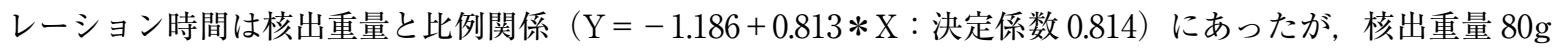
以上になると比例直線を逸脱して時間のかかるものが多くなり，特に $100 \mathrm{~g}$ 以上では 5 例が $66 \sim 90$ 分と長時 間要していた，モーセレーション効率は，核出重量 $80 \mathrm{~g}$ 以上で低下する傾向があり，100g 以上で有意に悪化 していた.

（結論）モーセレーション効率は核出重量が 80g 以上の大きなもので低下する可能性がある.

（日泌尿会誌 102(5)：675 678, 2011)

キーワード：前立腺肥大症, HoLEP, モーセレーション

\section{緒言}

当科では前立腺肥大症患者に対する経尿道的前立腺 核出術 (Holmium Laser Enucleation of the Prostate: HoLEP)におけるモーセレーションは hand-piece 反転法 で行っており, 合併症とモーセレーション効率の点にお いて安全かつ有効であることを報告している(1) 3).

一方で，デー夕を整理すると，モーセレーション時間 が極端に長いものが散見された. 特に大きな核出腺腫に おいてモーセレーション効率が低下する印象があるの で, モーセレーション効率と核出重量について検討した.

\section{対象と方法}

2010 年 1 月 5 日から 12 月 2 日までに当科で前立腺肥 大症患者に対して HoLEPを施行した 157 例のうち研修 医が関わった 17 例を除いた単一術者による 140 例を対 象とした. 途中レーザー出力の変更があり, 1 月 5 日から 5 月 18 日までの 56 例は $78 \mathrm{~W}(2.6 \mathrm{~J} \times 30 \mathrm{~Hz})$ で, 5 月 20 日から 12 月 2 日までの 84 例は $100 \mathrm{~W}(2.5 \mathrm{~J} \times 40 \mathrm{~Hz})$ で施 行した. 出力の違いはモーセレーション自体には影響を 及ぼさないため一括して後ろ向きに検討した.

手術手技：手術機器は, $26 \mathrm{Fr}$ 持続還流式切除鏡 (Karl Storz 社製または Olympus 社製), $30^{\circ}$ 光学視管, $550 \mu \mathrm{m}$
レーザーファイバー (Slimline $\mathrm{T}^{\mathrm{TM}}$ ，Lumenis 社製)を用い, ホルミウムヤグレーザー発生装置（VersaPulse ${ }^{\circledR}$ Select ${ }^{\mathrm{TM}}$, Lumenis 社製)の設定はパルス幅 $250 \mu \mathrm{sec}$ で, 78 $\mathrm{W}$ は $2.6 \mathrm{~J} \times 30 \mathrm{~Hz}, 100 \mathrm{~W}$ は $2.5 \mathrm{~J} \times 40 \mathrm{~Hz}$ とした. 手術行程 は最初に中葉を核出し, その後左右側葉を核出する Three-lobe technique に準じて行い, モーセレーション は hand-piece 反転法にて行った ${ }^{1) ~ 3) . ~}$

検討方法：患者背景として年齢, 経直腸的超音波検査 による前立腺推定体積（ml）について, 周術期のデータ として総手術時間 (分), 核出時間 (分), 核出重量 $(\mathrm{g})$, 核出効率 $(\mathrm{g} / \mathrm{min})$, モーセレーション時間 (分), モーセ レーション効率 $(\mathrm{g} / \mathrm{min})$, 総エネルギー量 $(\mathrm{kJ})$, 手術前 後のへモグロビン減少量 (術前〜翌日) $(\mathrm{g} / \mathrm{dl}$ ), 術後のカ テーテル留置期間 (日), 手術に伴う合併症の頻度につい て, 治療効果の判定として手術前および術後 1 力月目の 国際前立腺症状スコア (International Prostate Symptom Score : IPSS), Quality of life (QOL) index, 最大尿流量 率 $(\mathrm{Qmax})$ について検討した。

結果は平均值（範囲）で示し，統計解析はMannWhitney の U 検定, Wilcoxon の符号付順位検定, ピアソ ンの相関係数の検定を用い, $\mathrm{P}<0.05$ で統計学的有意差 を認めるとした。 
Table 1 患者背景・周術期データ・合併症

\begin{tabular}{|c|c|}
\hline 患者背景と周術期データ & 平均（範囲） \\
\hline 症例数 $(80 \mathrm{~W} / 100 \mathrm{~W})$ & $140(56 / 84)$ \\
\hline 年齢（歳） & $70.6(54-89)$ \\
\hline 推定前立腺体積（移行域）(ml） & $47.4(4.9-160.7)$ \\
\hline 推定前立腺体積（全体）（ml） & $73.6(9.1-260)$ \\
\hline 手術時間（分） & $67.2(18-223)$ \\
\hline 核出時間 (分) & $48.8(13-90)$ \\
\hline 核出重量（g） & $46.8(5-165)$ \\
\hline 核出効率（g/min） & $0.93(0.1-2.36)$ \\
\hline モーセレーション時間（分） & $9.9(1-90)$ \\
\hline モーセレーション効率（g/min） & $6.7(1.2-19)$ \\
\hline 総エネルギー量（kJ） & $132.6(26.8-332.7)$ \\
\hline 術後 Hb 低下（g/dl） & $1.6(0-4.9)$ \\
\hline カテーテル留置期間（日） & $1.9(1-11)$ \\
\hline \multicolumn{2}{|l|}{ 合併症 } \\
\hline 膀胱損傷 & - \\
\hline 同種血輸血 & - \\
\hline 尿失禁（3 カ月以上） & - \\
\hline 尿道狭窄 & 1 \\
\hline 膀胱澒部硬化症 & - \\
\hline
\end{tabular}

Table 2 治療効果

\begin{tabular}{lcc}
\hline & 平均 $($ 範囲 $)$ & $\mathrm{p}$-Value $($ 術前 vs 術後) \\
\hline IPSS score $($ 術前/術後 $)$ & $20.1(1-35) / 7.2(0-33)$ & $<0.0001$ \\
QOL index (術前/術後) & $4.8(0-6) / 1.7(0-6)$ & $<0.0001$ \\
Qmax $(\mathrm{ml} / \mathrm{s})$ (術前/術後 $)$ & $8.8(2.6-24) / 21.4(2.6-66.6)$ & $<0.0001$ \\
\hline
\end{tabular}

\section{結 果}

患者背景と周術期のデータと合併症を Table 1 に示 す. 対象の平均年齢は 70.6 歳で, 平均核出重量 $46.8 \mathrm{~g}$, 平 均モーセレーション時間 9.9 分, 平均モーセレーション 効率 $6.7(\mathrm{~g} / \mathrm{min})$ であった. 合併症は 1 例に尿道狭窄を 認めたのみで, 膀胱損傷, 輸血を必要とする出血, 持続 する腹圧性尿失禁, 膀胱䅡部硬化症は認めなかった (Table 1).

治療効果を Table 2 に示す. IPSS の total score 及び QOL index, 最大尿流量率のすべての項目において術前 に比べ術後は有意に改善していた（Table 2).

モーセレーション時間と核出重量の関係を Fig. 1 に示 す。モーセレーション時間と核出重量は全体としてみる と $\mathrm{Y}=-1.186+0.813 * \mathrm{X}$ の比例関係で表され, 決定係数 0.814 とグラフのあてはまりも良かった. 相関関係の検討 でも相関係数 $0.784(\mathrm{P}<0.0001)$ と強い相関を認めた. し かし, 核出重量 $80 \mathrm{~g}$ 以上になるとモーセレーション時間 はグラフの比例直線をはずれて時間のかかるものが大部 分を占めており, 更に $100 \mathrm{~g}$ 以上では 5 例が大きく逸脱 しており 66〜90 分とかなりの時間を要していた(Fig. 1). モーセレーション効率と核出重量の関係を Fig. 2 に示 す. モーセレーション効率は核出重量 $80 \mathrm{~g}$ 以下では平均
モーセレーション効率の $6.7 \mathrm{~g} / \mathrm{min}$ を超える効率の良い ものを多数認めるが, 核出重量 $80 \mathrm{~g}$ 以上になると平均值 を超えるものがほとんど無かった（Fig. 2).

核出重量別にみたモーセレーション効率の関係を Fig. 3 に示す. モーセレーション効率は, 核出重量 $80 \mathrm{~g}$ 以上で 低下する傾向があり，100g 以上で有意に悪化していた (Fig. 3).

\section{考察}

前立腺肥大症患者に対して腺腫を塊として膀胱内一核 出する HoLEP においては組織を取り出す方法が問題で あり，モーセレーターの完成によってこの術式が確立さ れたといっても過言ではない(4). しかし当初モーセレー ションは不安定な手技とされ, 特に膀胱損傷の頻度が 0.7〜 5.8\%であると報告されていた ${ }^{5 / 6)}$. 当科では 2006 年に hand-piece 反転法を導入して以来, 膀胱損傷の経験 はなく安全に行えるようになり，モーセレーション効率 も諸家の報告とくらべ遜色ない成績であった ${ }^{1) 31}$. しか し，モーセレーション時間が極端に長いものが散見され た. モーセレーションが長時間になる場合, 吸引チュー ブの加熱による吸引力低下を考慮し 20 分毎にモーセ レーターのポンプ部のチューブ位置を変更し, 改善がな ければチューブ自体を交換している。 それでもモーセ 
Fig. 1 モーセレーション時間と核出重量の関係

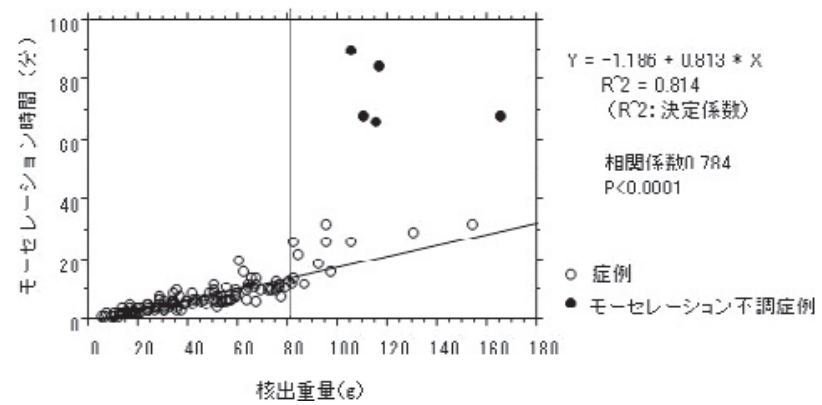

Fig. 2 モーセレーション効率と核出重量の関係

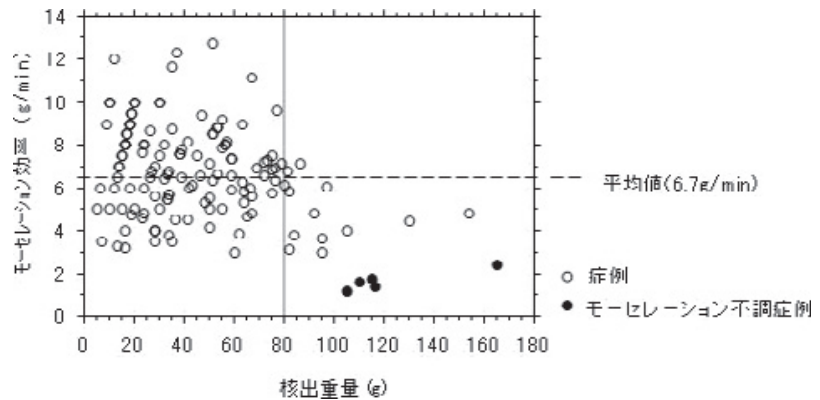

レーションが進まない場合はモーセレーションを中断 し，レーザーと TUR を用いて残存腺腫を細切し, TUR ループで把持して摘出している。 この作業は非常に時間 がかかるため, 特に大きな核出腺腫でモーセレーション 効率が低下した場合に問題となる.

今回の検討では, 全体としてみるとモーセレーション 効率は平均 $6.7 \mathrm{~g} / \mathrm{min}$ (範囲 1.2〜 19）であり（Table 1), 諸家の報告の $3.19 \sim 5.34 \mathrm{~g} / \mathrm{min}$ と比べても良好な成績で あった ${ }^{7) ~}$ ○)

一方で, モーセレーション効率は核出腺腫の大きさと 関係し, 核出重量 $80 \mathrm{~g}$ 以上で低下する傾向があり, 100 $\mathrm{g}$ 以上で有意に悪化していた (Fig. 1〜3). これらの症例 の映像を見直すと核出腺腫がブレード孔に噛みこみにく いため細切が進まないものが多かった，その理由として は, 大きな腺腫の場合, 表面のカーブが直線に近づく形 態となるため, ブレード孔に核出腺腫が噛み込みにくく なることが推測される. モーセレーション効率を改善す るための対策として側葉を二分割することを始めてい る. 症例数が少ないため今回は成績を示さないが，これ により個々の腺腫は 20～30g 程度の効率が良い大きさ となり，実際の効率にも改善がみられている.

\section{結語}

当科で前立腺肥大症患者に対して HoLEPを施行した 140 例を対象として, モーセレーション効率と核出重量 の関係について検討した. モーセレーション効率は核出 腺腫の大きさと関係し, 核出重量 $80 \mathrm{~g}$ 以上で低下する傾 向があり, $100 \mathrm{~g}$ 以上で有意に悪化していた.
Fig. 3 核出重量別にみたモーセレーション効率

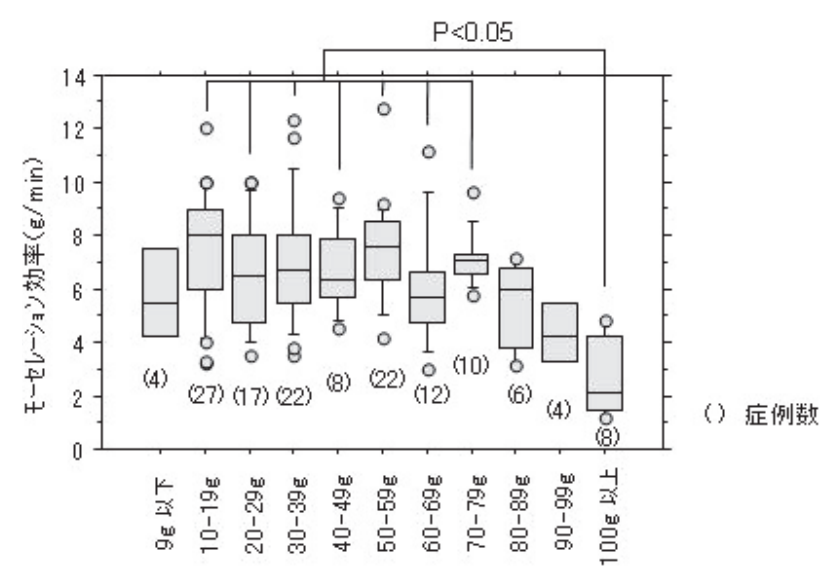

文

1）設楽敏也, 賀本敏行 : 前立腺肥大症の最新治療, HoLEP (1). Urology View, 6, 124-130, 2008.

2）設楽敏也：前立腺肥大症における HoLEP. 日レ医 誌, 29, 397-400, 2009.

3）平山貴博, 設楽敏也, 藤田哲夫, 久保星一, 岩村正嗣, 馬場志郎：Morcellation における hand piece 反転法 の有用性の実証. Jpn J Endourol ESWL， 23, 133137, 2010.

4) Gilling P.J., Kennett K., Das A.K., Thompson D. and Fraundorfer M.R.: Holmium laser enucleation of the prostate (HoLEP) combined with transurethral tissue morcellation: an update on the early clinical experience. J. Endourol, 12, 457-459, 1998.

5) Shah H.N., Mahajan A.P., Hegde S.S. and Bansal M. B.: Peri-operative complications of holmium laser enucleation of the prostate: experience in the first 280 patients, and a review of literature. Br.J.U. Int., 100, 94-101, 2007.

6) Seki N., Mochida O., Kinukawa N., Sagiyama K. and Naito S.: Holmium laser enucleation for prostatic adenoma: analysis of learning curve over the course of 70 consecutive cases. J.Urol., 170, 1847-1850, 2003.

7) Vavassori I., Hurle R., Vismara A., Manzetti A. and Valenti S.: Holmium laser enucleation of the prostate combined with mechanical morcellation: two years of experience with 196 patients. J. Endourol, 18, 109-112, 2004.

8) Shah H.N., Mahajan A.P., Sonda H.S., Hedge S., Mohile P.D. and Bansal M.B.: Prospective evaluation of the learning curve for Holmium laser enucleation of the prostate. J.Urol., 177, 1468-1474, 2007.

9) Krambeck A.E., Handa S.E. and Lingeman J.E.: Holmium laser enucleation of the prostate for prostates larger than 175 grams. J. Endourol., 24, 433-437, 2010. 


\title{
RELATIONSHIP BETWEEN MORCELLATION EFFICIENCY AND ENUCLEATED TISSUE WEIGHT IN HOLMIUM LASER ENUCLEATION OF THE PROSTATE (HOLEP) FOR PATIENTS WITH BENIGN PROSTATIC HYPERPLASIA
}

\author{
Ryuta Ishikawa ${ }^{133}$, Toshiya Shitara ${ }^{12}$, Yoji Wakatabe ${ }^{122}$, Seiichi Kubo ${ }^{12}$, Takahiro Hirayama ${ }^{21}$, \\ Tetsuo Fujita ${ }^{2)}$, Masatsugu Iwamura ${ }^{2)}$ and Shiro Baba ${ }^{2)}$ \\ ${ }^{1)}$ Department of Urology, Fuchinobe General Hospital \\ ${ }^{2)}$ Department of Urology, Kitazato University School of Medicine \\ ${ }^{3)}$ Ishikawa Urology Clinic
}

\begin{abstract}
:
(Objective) We examined the relationship between morcellation efficiency and enucleated tissue weight in holmium laser enucleation of the prostate (HoLEP) for patients with benign prostatic hyperplasia (BPH) retrospectively.

(Methods) From January to December 2010, 140 patients with BPH were treated by HoLEP combined with mechanical morcellation with up side down technique by a single surgeon.

(Results) The mean age was 70.6 years, and the mean enucleated tissue weight was $46.8 \mathrm{~g}$. The mean morcellation time was $9.9 \mathrm{~min}$, and the mean rate of morcellation was $6.7 \mathrm{~g} / \mathrm{min}$. No complications were reported relating to morcellation such as bladder injury. Although morcellation time and enucleated tissue weigh were proportionally related (Estimate equation: $\mathrm{Y}=-1.186+0.813 * \mathrm{X}, \mathrm{R}^{\wedge} 2: 0.814$ ), larger glands with more than $80 \mathrm{~g}$ of tissue enucleated did not match this distribution map. Five cases with more than $100 \mathrm{~g}$ of enucleated tissue weight required much longer operation time (range 66-90 min) and were disproportioned to tissue weight. Morcellation efficiency tended to decrease when enucleated tissue weight exceeds $80 \mathrm{~g}$ and less than average in almost all cases. Morcellation efficiency significantly worsen when enucleated tissue weight exceeds more than $100 \mathrm{~g}$.

(Conclusions) Morcellation efficency may decrease in larger gland exceeds $80 \mathrm{~g}$.
\end{abstract}

(Jpn. J. Urol 102(5): 675-678, 2011)

Keywords: BPH, HoLEP, morcellation

Received: January 28, 2011, Accepted: June 1, 2011

(C) 2011 Japanese Urological Association 